\title{
The Last Fifteen Years of Schistosomiasis in Venezuela: Features and Evolution
}

\author{
Belkisyolé Alarcón de Noya/ ${ }^{+}$, Carlos Balzan*, César Arteaga*, Italo Cesari**, \\ Oscar Noya
}

Instituto de Medicina Tropical, Universidad Central de Venezuela, Apartado Postal N 47623, Zona Postal 1041-A, Los Chaguaramos, Caracas, Venezuela *Dirección General Sectorial de Malariología y Saneamiento Ambiental, MSAS, Maracay, Venezuela **Centro de Microbiología, IVIC, Caracas, Venezuela

Control of schistosomiasis in Venezuela has been a topic of major interest and controversy among the metaxenic parasitosis. A small area of transmission of approximately 15,000 $\mathrm{km}^{2}$ was thought to be eradicated some years ago. However, some epidemiological characteristics of our transmission area have limited the success on the way toward eradication. Since 1945, when the Schistosomiasis Control Program started, the prevalence in the endemic area has decreased from 14\% in 1943 to $1.4 \%$ in 1996. Until 1982, the surveillance of active cases was based on massive stool examination. Since then, the Schistosomiasis Research Group (SRG) recommended the additional use of serologic tests in the Control Program and the selective or massive chemotherapy depending on serological and parasitological prevalence of each community. At present, the real prevalence is underestimated due to the fact that approximately $80 \%$ of the individuals eliminate less than $100 \mathrm{eggs} / \mathrm{g}$ of feces. Those persons could be responsible for the maintenance of the foci going on and therefore limiting the impact of the control measures.

Efforts of the SRG are being oriented toward improvement of immunodiagnostic tests by using defined antigens (enzymes) and chemically synthesized peptides, derived from relevant molecules of the parasite, either for antibodies or antigens search. On the other hand, introduction of snail competitors has been a biological weapon in the control of the intermediate host in certain areas. However, the recent reinfestation of water courses by Biomphalaria glabrata, the increased prevalence in some areas, together with important administrative changes at the Control Program of the Minister of Health, have arisen new questions and doubts, challenging the eradication strategy proposed during the last decade.

Key words: schistosomiasis - Venezuela - epidemiology and control

\section{BRIEF HISTORICAL NOTE}

The history of schistosomiasis in Venezuela starts in 1905, when Soto described the first human case. Later on, in 1917, Iturbe described the intermediate host as Planorbis guadeloupensis (Iturbe 1955). The first control measures were initiated in 1922 in spite of the fact that the snail distribution was not known in the country. But only in 1943 the Schistosomiasis Control Program (SCP) initiated its activities as a formal structure in the Minister of Health (Incani 1987). Forty years

This work has been supported by projects of "Control de Enfermedades Endémicas" PCEE-PNUD VEN/96/ 002, Dirección de Endemias Rurales, and Project 0934-3596-95 of the CDCH-UCV and presented at the 6th International Symposium on Schistosomiasis.

${ }^{+}$Corresponding author. Fax: +58-2-693.0454. E-mail: alarconb@camelot.rect.ucv.ve

Received 4 May 1998

Accepted 31 August 1998 later, in 1984, a group of investigators and people related to the Control Program, agreed to create the Schistosomiasis Research Group (SRG).

Reviews on the epidemiology of schistosomiasis in Venezuela have been reported by Luttermoser (1946), Jove and Marsewski (1955), Gabaldón (1964), Incani (1987), Balzán (1988), Noya et al. (1991) and Rey (1992) among others.

\section{OVERALL SITUATION UNTIL 1982}

In 1946, the endemic area was estimated in $7,000 \mathrm{~km}^{2}$ with 70,000 human cases (Gabaldón $1985)$ in the northern central region of the country, formed by the states Vargas, Miranda, Aragua, Carabobo and north of Guárico. This area was later estimated in $15,000 \mathrm{~km}^{2}$ of the territory, which corresponds to $40 \%$ of the Venezuelan population.

Although since 1943 the prevalence in the endemic area had been relatively low (14.7 to $0.6 \%$ ) (Table I) the schistosomiasis distribution in Venezuela did not follow an homogenous pattern. In fact, high focal transmission was found in some localities such as the Caracas valley with $29.1 \%$, 
Aragua 24.8\%, Miranda $10.3 \%$ and Carabobo states $9.9 \%$ (Incani 1987).

Successful control has relayed mainly on snail killing and environmental measures that avoid infected water contact of communities. In relation to snail control, the activities of the SCP were mostly dedicated to application of molluscicide and sanitary engineering. Additional control measures were based on periodical sanitary education and treatment of infected individuals. These activities reduced the prevalence as can be seen in Table I, but were not able to reduce the size of the endemic area (Fig. 1). Moreover, new breeding places of Biomphalaria glabrata appeared in states neighbouring the traditional endemic area such as Portuguesa, Lara and Cojedes (Otero et al. 1986).
TABLE I

Schistosomiasis prevalence based on stool examination in the Venezuelan endemic area (1943-1988)

\begin{tabular}{lrrr}
\hline Periods & $\begin{array}{c}\text { Persons } \\
\text { examined }\end{array}$ & $\begin{array}{c}\text { Positive } \\
\text { cases }\end{array}$ & $\begin{array}{c}\text { Prevalences } \\
\%\end{array}$ \\
\hline $1943-1960$ & 87639 & 12851 & 14.7 \\
$1961-1965$ & 126948 & 10424 & 8.2 \\
$1966-1970$ & 173645 & 6916 & 4.0 \\
$1971-1975$ & 235656 & 4686 & 2.0 \\
$1976-1980$ & 158519 & 3064 & 1.9 \\
$1981-1984$ & 82877 & 774 & 0.9 \\
$1985-1988$ & 119651 & 768 & 0.6 \\
\hline
\end{tabular}

Source: Balzan 1988, "División de Parasitosis Intestinales, Dirección de Endemias Rurales, Malariología, MSAS", Venezuela.
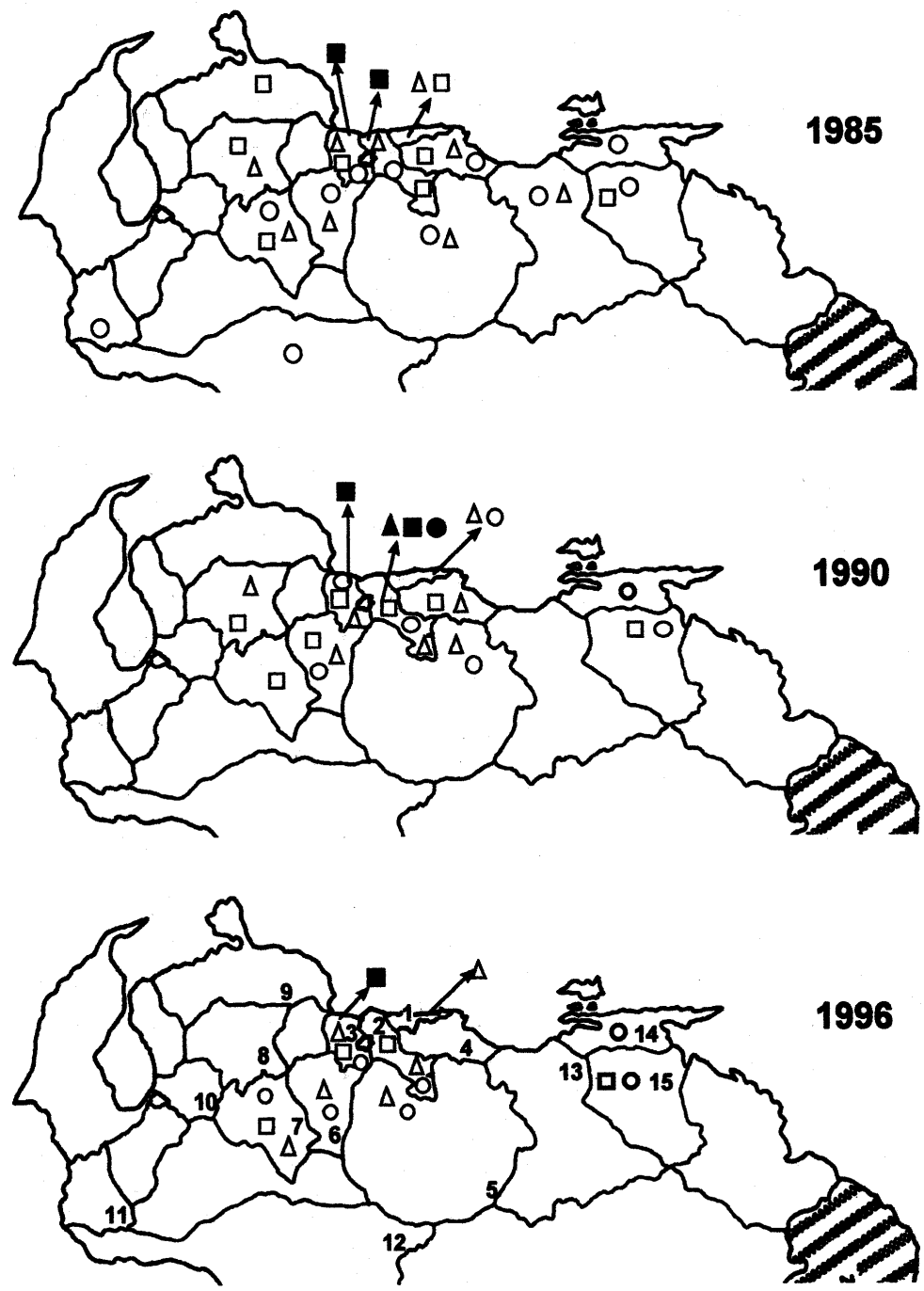

Fig. 1: Biomphalaria sp. Distribution and infected snails in Venezuela from 1985 to 1996, $\square$ B. glabrata, $\triangle B$. straminea, $\square$ B. prona; $\square \boldsymbol{\Delta} \square$ infected snails. 1. Vargas 2. Aragua 3. Carabobo 4. Miranda 5. Guárico 6. Cojedes 7. Portuguesa 8. Lara. 9. Falcón 10. Trujillo 11. Táchira 12. Apure. 13. Anzoátegui 14. Sucre 15. Monagas ///Claimed zone. 
Transmission of Schistosoma mansoni was reported on the western states of Lara and Portuguesa, from the Chabasquén river basin, with 70 human cases ("Memoria y Cuenta del MSAS" 1979-1981, unpublished results).

Diagnosis was based in one Kato smear of feces per person and no quantification of intensity of infection was recorded. Chemotherapy was restricted to infected persons. As in the rest of the world, attention was oriented toward snail elimination, and passive search of schistosomiasis was the rule. However at national level, large surveys within the Intestinal Parasites Program in which $S$. mansoni was included, were performed (Benarroch 1966).

\section{SCHISTOSOMIASIS IN VENEZUELA (1982-1997)}

Snail surveillance and control - In Venezuela, three species of Biomphalaria are commonly found, B. glabrata, B. straminea, and B. prona. B. glabrata is the intermediate host responsible for the schistosomiasis transmission in the endemic area, which has been traditionally located at the northern central region of the country. However, B. glabrata has been found out of this area. In order to illustrate it and to give an idea of its evolution, we selected three cross sectional studies on the distribution of the three more important species of snails (Fig. 1). Between 1982 and 1987 B. glabrata was detected in five states out of the classical endemic region. A similar situation was found with $B$. straminea, the second important intermediate host of $S$. mansoni in Venezuela, since it was reported in all states of the endemic area plus four additional states. But, infected B. glabrata was only found from Aragua and Carabobo states. In 1990 (period 1987-1992) the Biomphalaria sp. fauna was restricted to the central region and infected snails were found again in Aragua and Carabobo states. In this period (1987-1992) in the locality of Turmero (Aragua state) B. straminea and B. prona were also found naturally infected with $S$. mansoni.

For the period 1992-1997 (year 1996 in Fig. 1) the reports on malacological fauna were scarce. Several infected $B$. glabrata lots were reported from Carabobo state only, with frequencies of infections over $6.25 \%$ of the captured snails, in the localities of Güigüe, Manuare and Valencia. The reduced reports of this period were partially due to the efforts of the SCP in reducing the snail population with chemical molluscicides, together with administrative changes that brought budget restrictions and consequent decrease of field surveys that have not allowed snail collections.

An important aspect is that stagnant water streams with high level of organic pollution are highly favorable to B. glabrata (Mott et al. 1990).
New human settlements have occurred in the endemic area and B. glabrata has colonized periurban streams which receive sewer waters from these marginal villages (Caraballeda in Vargas state and quarters at the south of Valencia city and Valencia lake).

The invasion by thiarid snails of the rivers of the seashore of Carabobo, Aragua and Vargas states is an important phenomenon. Prior to 1975, seven of these rivers harbored B. glabrata and one of them used to be the only active transmission site of the Distrito Federal (Alarcón de Noya et al. 1987). Several surveys until 1990 revealed that Thiara granifera and Melanoides tuberculata had displaced B. glabrata from this littoral (Pointier et al. 1994). Introduction of thiarid snails to Valencia lake region resulted in the elimination of Biomphalaria sp. from artificial ponds but this was not the case in streams and rivers (Pointier et al. 1991).

Outside the endemic region there are two areas with B. glabrata in Caripe (Monagas state) and in the confluence of Lara, Portuguesa and Trujillo states. In Caripe, B. glabrata has been considered resistant to $S$. mansoni infection (Romero-Morrel \& Marta 1978), nevertheless recent studies have revealed that they are susceptible to infection (Moreno-Alvarez \& Delgado 1992). This region as well as Portuguesa, Cojedes and Lara deserve more attention since the susceptible $B$. glabrata is present in all of them. B. prona is widely distributed in the country but does not seem to be a risky specie due to its lower susceptibility.

Active search of infected human cases - Although the SCP has the entire responsability on the disease control, researchers from three different institutions joined to this program in order to configure a multidisciplinary group (SRG).

There has been a progressive diminution in the surveillance activities as reflected by the lower number of individuals evaluated by stool examination in the last 15 years. Serologic samplings have not compensated the decrease in stool examination (Table II).

Since 1985 , a strategy was undertaken pointing to look for active cases and to work on the infected populations. The SCP together with the SRG decided to incorporate serological studies as additional technique of diagnosis in the Control Program. This new strategy was based on the initial screening by ELISA with soluble egg antigen (ELISA-SEA) and confirmation of seropositives by circumoval precipitin-test (COPT) and KatoKatz (Alarcón de Noya et al. 1992c). A summary of cross sectional studies carried out in the endemic area by different workers is shown in Table III. Although not all of them followed the same protocol, the results reveal that active cases have been 
TABLE II

Schistosomiasis prevalence in Venezuela, based on stool examination and ELISA-SEA from 1982 to 1996

\begin{tabular}{|c|c|c|c|c|c|c|}
\hline \multirow[b]{2}{*}{ Periods } & \multicolumn{3}{|c|}{ Stool examination } & \multicolumn{3}{|c|}{ ELISA-SEA } \\
\hline & $\begin{array}{l}\text { Persons } \\
\text { examined }\end{array}$ & $\begin{array}{c}\text { Positive } \\
\text { cases }\end{array}$ & $\%$ & $\begin{array}{l}\text { Persons } \\
\text { examined }\end{array}$ & $\begin{array}{c}\text { Positive } \\
\text { cases }\end{array}$ & $\%$ \\
\hline $1982-1986$ & 131777 & 933 & 0.71 & nd & nd & nd \\
\hline $1987-1991$ & 113746 & 675 & 0.59 & 6953 & 1839 & 26.4 \\
\hline $1992-1996$ & 17945 & 249 & 1.39 & 11679 & 2405 & 20.6 \\
\hline
\end{tabular}

nd: not determined.

TABLE III

Cross-sectional studies on schistosomiasis in Venezuela 1985-1997

\begin{tabular}{|c|c|c|c|c|c|c|}
\hline Localities & Year & $\begin{array}{l}\text { Persons } \\
\text { examined }\end{array}$ & $\begin{array}{c}\text { ELISA-SEA } \\
\text { prevalence } \\
(\%)\end{array}$ & $\begin{array}{c}\text { PPCO } \\
(\%)\end{array}$ & $\begin{array}{c}\text { Kato- Katz } \\
\text { prevalence } \\
(\%)\end{array}$ & References \\
\hline Caraballeda & 1985 & 896 & nd & nd & 12.2 & Alarcón de Noya 1987 \\
\hline El 25 & 1986 & 348 & nd & nd & 24.9 & Lara et al. 1987 \\
\hline Bicentenario & 1989 & 2500 & 35.6 & nd & nd & $a$ \\
\hline Belen & 1990 & 436 & 30.5 & 10.5 & nd & $a$ \\
\hline Los Naranjos & 1991 & 418 & 37.0 & 13.4 & 20.8 & Alarcón de Noya 1992a \\
\hline Chuao & 1992 & 543 & 23.0 & 24.7 & 0.2 & Alarcón de Noya 1992b \\
\hline Seitifero & 1992 & 328 & nd & 77.0 & 30.0 & Delgado et al. 1992 \\
\hline Guatire-Araira & 1992 & 446 & 8.5 & nd & nd & $a$ \\
\hline Santa Rosa & 1992 & 562 & nd & 47.0 & 14.0 & Delgado et al. 1992 \\
\hline Manuare & 1993 & 520 & nd & 34.0 & 3.2 & Delgado et al. 1992 \\
\hline Los Magallanes & 1993 & 687 & 22.0 & nd & nd & 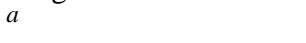 \\
\hline Anzoátegui & 1993 & 90 & 15.5 & 16.6 & nd & $a$ \\
\hline Manuare & 1996 & 133 & nd & 33.0 & 6.8 & García el al. 1997 \\
\hline Los Naranjos & 1996 & 177 & nd & 59.8 & 46.0 & Sanchez et al. 1997 \\
\hline Caraballeda & 1997 & 188 & 38.0 & 10.6 & 1.0 & $a$ \\
\hline Los Mangos & 1997 & 126 & 22.2 & 7.9 & 0.0 & $a$ \\
\hline Bicentenario & 1997 & 331 & 15.1 & nd & nd & $a$ \\
\hline S. Juan Morros & 1997 & 126 & nd & 14.0 & nd & $b$ \\
\hline
\end{tabular}

$a$ : Alarcón de Noya et al.; $b$ : Arteaga et al. pers. comm.; nd: not determined.

present in high percentages throughout the last fifteen years. We consider as active cases, those persons with eggs of $S$. mansoni in the stools or positive by COPT. In all stool examination-based studies, the intensity of infection was low since 70$80 \%$ of cases excreted less than 100 eggs/g of feces. However, the parasitologic prevalence has been high in certain localities: $24.9 \%$ in "El 25 " in 1986, 13.4\% in "Los Naranjos" in 1991, 30\% in "Manuare" 1992 and 46\% in "Los Naranjos" 1996. This clustering distribution resembles the data presented by Tsang et al. (1997) in Puerto Rico, a country of low intensity of infection.

An age dependent Kato diagnosis has been demonstrated, suggesting that the number of Kato slides seems to be critical in the evaluation of true prevalence. In areas with infections greater than 100 eggs/ $\mathrm{g}$ of feces, six Kato smears from three stool samples per person can better approximate to the real preva- lence in people older than 20 years of age (Gryseels 1996). To infer "true" prevalences from simple count fecal surveys, De Vlas et al. (1993) have proposed a practical chart to avoid underestimation. In Venezuela, six Kato-Katz smears from two stool samples are performed, which is probably insufficient based on the very low intensities of infection. The ideal number is unrealistic, under our socioepidemiological and administrative condition.

Transmission of $S$. mansoni is still active based on the presence of young infected individuals. From studies of Table III, "Belen" and "Los Naranjos", 1990 and 1991 and "Los Naranjos" 1996 (Salas et al. 1997), 85.5\% of the egg-excreting people was between 5 to 19 years old.

ELISA-SEA as a first screening search clearly overestimates the prevalence (Table III). Some of us have worked with a locally developed test, the alkaline phosphatase immunoassy (APIA) compar- 
ing it with ELISA-SEA and COPT (Alarcón de Noya et al. 1997). We also work in a SEA treated with sodium metaperiodate (SMP), which improves specificity of ELISA-SEA (Colmenares et al. 1998). A field survey is under way to evaluate if APIA or ELISA-SMP could be selected as first screening methods instead of ELISA-SEA. APIA has shown to be highly sensitive, $93 \%$, and $100 \%$ specific (Pujol et al. 1989). One of the strongest arguments favoring the switch from ELISA to APIA or ELISA-SMP is their higher specificity, since it is well known that people infected with intestinal nematodes cross react with $S$. mansoni antigens (Correa-Oliveira et al. 1988) and give false positives in ELISA-SEA (Alarcón de Noya et al. 1996).

Recent efforts of the SRG are oriented toward development of antigen detection techniques, using polyclonal antibodies from animals immunized with synthetic peptides or monoclonal antibodies to known molecules of $S$. mansoni.

COPT continues to be our gold standard technique due to its high sensitivity, specificity and correlation with active cases (Alarcón de Noya et al. 1992d). The COPT prevalence in cross-sectional studies is shown in Table III. A range of 8 to $77 \%$ has been found, being always these values higher than stool examination, suggesting that there are more persons infected than those excreting eggs in the feces.

The integrated analysis of the central endemic area is the key for the control of schistosomiasis in Venezuela. In Fig. 2, we have marked the outer limits of the main basins where schistosomiasis transmission takes place and the prevalence of active cases (stool examination and COPT). Few studies have been done in the two largest basins of Valencia lake and Guárico river in which three big cities are located. Instead, Manuare and Los Naranjos river basins have been subjected to chemical molluscicides and massive praziquantel treatment and, although prevalence has decreased, they still remain active.

An unknow number of individuals with low parasite loads has been probably responsible for the maintenance of ongoing foci in the endemic area. This reflects the difficulties in the eradication of this disease, since selective treatment of the positive cases is the main control measure, leaving aside an important percentage undetectable by the current diagnostic methods.

Morbidity - Few epidemiological studies have concerned morbidity. Results from four cross sec-
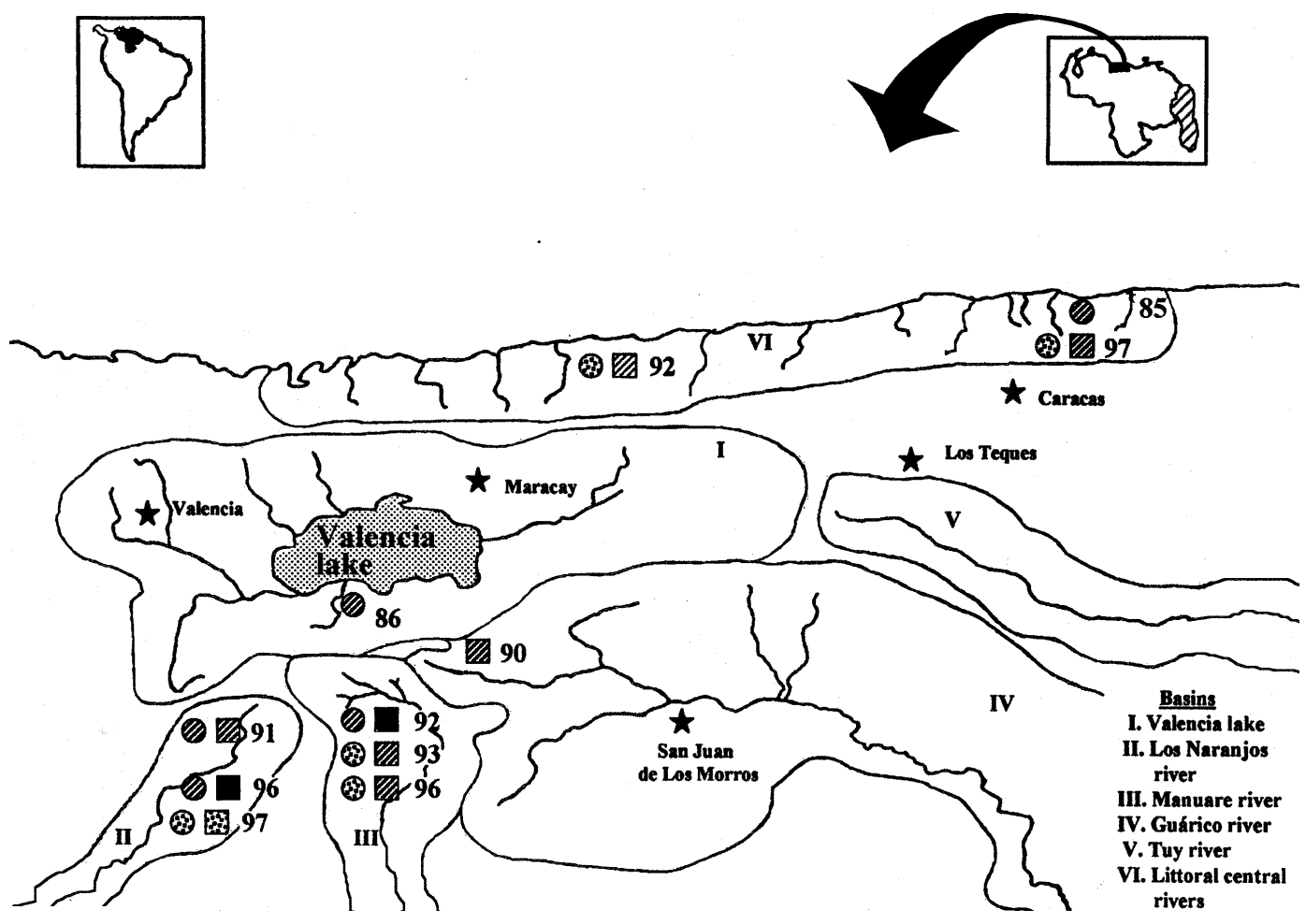

Fig. 2: focal transmission in Venezuela endemic basins. Stool examination prevalences precipitation test prevalences $\mathbb{Q} 0-10 \% \quad \square 10-50 \% \quad \square>50 \%$. 
tional studies in Table III have revealed that intestinal form predominates ranging from 60 to $85 \%$, while hepatointestinal forms represent 15 to $38 \%$. Hepatosplenic clinical form is rare, one or two cases were reported from these studies (Lara et al. 1987, Alarcón de Noya et al. 1992b, García et al. 1997, Sánchez et al. 1997).

Cases from hospitals and private physicians are usually not recorded, mainly because this is not an obligatory denounced disease. From 290 out patient consultation at Tropical Medicine Institute, we have diagnosed in the last five years 56 individuals being $10.7 \%$ intestinal, $39.2 \%$ hepatointestinal and $50 \%$ hepatosplenic forms. A case of mielitis for $S$. mansoni was reported in a 15 years old girl from the Distrito Federal focus (Caraballeda) in 1985 (González \& Céspedes, pers. comm.).

Chemotherapy - Based on the World Healt Organization recommendations (WHO 1985), the SCP adopted in 1987 the new strategy of control based on chemotherapy and two algorithms were accepted, one for diagnosis and one for chemotherapy. Selective treatment was restricted to detected cases when COPT or Kato Katz prevalence were less then $20 \%$ and massive treatment when prevalence was higher than $20 \%$ (Alarcón de Noya et al. 1992c). However, pressure for eradicate the disease plus political changes made massive treatments to be administrated twice or without previous evaluation of prevalence. At the present time, chemotherapy guidelines and follow-up studies to measure impact of chemotherapy must be achieved specially in view of increasing problems of drug resistance (Redman et al. 1996)

Administrative and political changes - A political and administrative decentralization process has been undertaken in Venezuela since 1992. Each state is autonomous in its health policies and the surveillance of endemic infection disease depends more and more on the administration of each state. Decentralization has been a progressive process in which the Aragua and Carabobo states were the ones first involved. Other temporary endemic problems such as dengue or cholera have occupied much of the attention and resources, leaving aside the surveillance and control of traditionally endemic diseases as intestinal parasitosis and schistosomiasis.

The new administrative tendency is to eliminate the vertical programs of "malariologia", reinforcing the role of rural clinics and hospitals in the diagnosis and control of these endemies. However, as a consequence of low intensity of infection and low morbidity, the patients with schistosomiasis are rarely diagnosed and reported. In this sense, management of $S$. mansoni infected human popu- lations and search for active cases can not be dependent on hospital workers. For this reason, SRG has proposed that in certain endemies as schistosomiasis it should be evaluated the maintenance of a vertical program directed by the SCP on the main water basins, based on sanitary education, active surveillance of cases, chemotherapy and snail control. A cost-effective evaluation should be carried out also.

It is early to evaluate the impact of this political decision on the course of endemic, chronic diseases as schistosomiasis. New strategies in this sense must be implemented jointly to the regional authorities to avoid more dispersion of the susceptible snail and infection of human populations at risk.

\section{FINAL COMMENTS}

The review of the epidemiological situation of schistosomiasis in Venezuela in the last 15 years is critically analyzed. First of all, the surveillance does not seem to be as effective as used to be in the 70th decade, based on the reduced number of persons examined by stool examination and/or by serology. A similar situation has been observed with the malacological inspections, which do not reflect the real situation of the Biomphalaria sp. distribution and densities in the country. Probably this is the consequence of political and administrative decisions commented above, in which the geopolitical borders of the states limit the activities of the SCP.

We have outlined the main schistosomiasis transmission basins, which include rivers, lakes, streams, ponds and dams. Five basins and one littoral region can be identified as risky areas. In this way, a small labor group of the SCP together with regional authorities could work in both actions, snail and population surveillance and control. Also, the study of these basins by remote sensing images might give valuable information helping to the detection of possible Biomphalaria sp. breeding places. Special attention deserves the localities out of the endemic area where some epidemiologic conditions for the establishment of schistosomiasis transmission exist.

The strategy of control, based mainly on chemotherapy must be revised. At the present time, there are no alternative drugs to praziquantel and oxamniquine and, at world level, few groups are working on the discovery of new drugs. For this reason, control programs must rescue other measures that have been relegated after the arrival of oxamniquine and praziquantel. These measures are sanitary education to the general population with special emphasis in school children, community participation and environmental sanitation. 
Reduced morbidity and mortality, low intensity of infection, natural biological control of $B$. glabrata in some areas and introduction of serology in the control program have been the most important achievements in the last 15 years.

Time has demonstrated that in spite of good diagnostic tools for active cases, a wonderful drug against $S$. mansoni and a small area of focal sites of transmission, schistosomiasis has proved to be difficult to eradicate if other control measures that avoid fecal human contamination of water bodies are not implemented.

\section{ACKNOWLEDGMENTS}

To Dr Nino Incani, Carmen Sierra, Liboria Matinela, Lourdes de Belmonte and Homero Coello, for help in collection of data and to Henry Bermudez, Cecilia Colmenares and Sandra Losada for technical assistance in the manuscript elaboration.

\section{REFERENCES}

Alarcón de Noya B, Balzan C, Colmenares C, Rodríguez M, Spencer L, Rodríguez E, González M, Stojanovic A, Ruíz E, Romero F, Masroua G, Noya O 1992a. Esquistosomiasis en el caserío de Los Naranjos, Estado Carabobo. Act Cient Venez 43 (Suppl. 1): 201.

Alarcón de Noya B, Balzan C, Noya O, Matinela L, Colmenares C, Spencer L, Contreras R, Coutinho M, Zerpa B, Ayala J, González S, Garban H 1992b. Esquistosomiasis en la población de Chuao, Estado Aragua. Act Cient Venez 43 (Suppl. 1): 201.

Alarcón de Noya B, Cesari I M, Losada S, Colmenares C, Hoebeke J, Noya O 1997. Evaluation of alkaline phosphatase immunoassay and comparison with other diagnostic methods in areas of low transmission of schistosomiasis. Acta Trop 66: 69-78.

Alarcón de Noya B, Colmenares C, Losada S, Masroua G, Ruíz L, Soto L, Noya O 1996. Do intestinal parasites interfere with the seroepidemiologic surveillance of Schistosoma mansoni infection? Epidemiol Infect 116: 323-329.

Alarcón de Noya B, Noya O, Balzan C, Cesari I M 1992c. New approaches for the control and eradication of schistosomiasis in Venezuela. Mem Inst Oswaldo Cruz 87 (Suppl. IV): 227-231.

Alarcón de Noya B, Noya O, Urbaez R, Risquez J 1987. Reactivación del foco bilharziano de Caraballeda en 1980-83. Bol Dir Malariol y San Amb 27: 86-93.

Alarcón de Noya B, Spencer L, Noya O 1992d. Pre and post-treatment immunodiagnostic evaluation in human schistosomiasis mansoni. Mem Inst Oswaldo Cruz 87: 271-276.

Balzán C 1988. Programa de lucha contra la esquistosomiasis en Venezuela. Dirección General Sectorial de Malariología y Saneamiento Ambiental. Dirección de Endemias Rurales, 20 pp.

Benarroch E 1966. Las Helmintiasis Intestinales Como Problema de Salud Pública, Ministerio de Sanidad y Asistencia Social, $436 \mathrm{pp}$.

Colmenares C, Alarcón de Noya B, Caracciolo M A, Losada S, Noya O 1998. ELISA-ASH con meta- periodato de sodio como alternativa de ensayo diagnóstico en la vigilancia seroepidemiológica de esquistosomiasis. Act Cient Venez 49 (Suppl. 2): 299.

Correa-Oliveira R, Dusse LMS, Viana IRC, Colley D G, Carvalho OSF, Gazzinelli G 1988. Human antibody responses against schistosomal antigens antibodies from patients with Ancylostoma, Ascaris lumbricoides or Schistosoma mansoni infections react with schistosome antigens. Am J Trop Med Hyg 38: 348-355.

De Vlas SJ, Gryseels B, van Oortmarssen GJ, Polderman AM, Habbema JD 1993. A pocket chart to estimate true Schistosoma mansoni prevalences. Parasitol Today 9: 305-307.

Delgado VS, Moy B, Lara I, Balzan C1992. Esquistosomiasis: Estudio epidemiológico en dos caseríos del valle de Manuare (Edo Carabobo). Act Cient Venez 43 (Suppl. 1): 202.

Gabaldón A 1964. Recent development in the control of bilharziasis in Venezuela. Expert Committee on Bilharziasis. OMS Bilh Exp Com 3/WP31.

Gabaldón A 1985. Posibilidad de la erradicación de la esquistosomiasis o bilharziasis en Venezuela. Bol Dir Malariol y San Amb 25: 118.

García FA, Aular SM, Loaiza LC, Balzan C, Incani RN 1997. Frecuencia y morbilidad de la esquistosomiasis mansoni en una población tradicionalmente endémica, Seitifero-Valle de Manuare, al sur del Estado Carabobo. Act Cient Venez 48 (Suppl. 1): 172.

Gryseels B 1996. Uncertainties in the epidemiology and control of schistosomiasis. Am J Trop Med Hyg 55: 103-108.

Incani RN 1987. The Venezuelan experience in the control of schistosomiasis mansoni. Mem Inst Oswaldo Cruz 82 (Suppl. IV): 89-93.

Iturbe J 1955. Historia de la schistosomiasis mansoni en Venezuela GEN 10: 33-59.

Jove JA, Marsewski P 1955. La bilharziosis en Venezuela desde el punto de vista sanitario. GEN 10: 119-194 .

Lara O, Leañez C, Maldonado M, Martínez C, García JA, Incani RN 1987. Esquistosomiasis mansoni en una población rural al sur del Lago de Valencia I. Epidemiolgía. Act Cient Venez 38 (Suppl. 1): 226.

Luttermoser G 1946. La campaña antibilharziana en Venezuela. XII Conferencia Sanitaria Panamericana. Cuadernos Amarillos 12: 74.

Moreno-Alvarez MJ, Delgado VS 1992. Susceptibilidad de Biomphalaria glabrata procedente de zona no endémica a la infección por Schistosoma mansoni. Act Cient Venez 43 (Suppl. 1): 202.

Mott K E, Desjeux P, Moncayo A, Ranque P, de Raadt $P$ 1990. Parasitic diseases and urban development. Bull WHO 68: 691-698.

Noya O, Balzan C, Cesari IM, Alarcón de Noya B 1991. Progress in control of schistosomiasis in Venezuela. WHO SCH/EC/91WP 37.

Otero MA, Balzan C, Camejo T, Chrosciechowski P, Pereira P 1986. Programa de Lucha contra la Bilharziasis, Minister of Health, $1120 \mathrm{pp.}$

Pointier JP, Balzan C, Chrosciechowski P, Incani RN 1991. Limiting factors in biological control of the 
snail vectors of schistosomiasis in Venezuela. $\mathrm{J} \mathrm{Med}$ Appl Malacol 3: 53-67.

Pointier JP, Incani RN, Balzan C, Chrosciechowski P, Prypchan S 1994. Invasion of rivers of the Littoral Central Region of Venezuela by Thiara granifera and Melanoides tuberculata (Mollusca: Prosobranchia: Thiaridae) and the abscense of Biomphalaria glabrata snail host of Schistosoma mansoni. The Nautilus 107: 124-128.

Pujol FM, Alarcón de Noya B, Cesari IM 1989. Immunodiagnosis of schistosomiasis mansoni with APIA (Alkaline Phosphatase Immunoassay). Immunol Invest 18: 1071-1080.

Redman CA, Robertson A, Fallon PG, Modha J, Kusel JR, Doenhoff MJ, Martin RJ 1996. Praziquantel: an urgent and exciting challenge. Parasitol Today 12: $14-20$.

Rey L 1992. Informe sobre la situación de la lucha contra la esquistosomiasis en Venezuela. OPS Venezuela. Informe técnico al Ministerio de Sanidad, $11 \mathrm{pp}$.

Romero-Morrell J, Marta C 1978. Estudio sobre la susceptibilidad de una cepa de Biomphalaria glabrata de Venezuela a la infección con dos diferentes cepas de Schistosoma mansoni. Rev Inst Med Trop São Paulo 20: 318-322.

Salas RM, Sánchez IB, Rodríguez R, Aular SM, Loaiza LC, Balzán C, Incani RN 1997. Esquistosomiasis en el Valle de Los Naranjos, Estado Carabobo, un foco de alta transmisión I. Epidemiología básica. Act Cient Venez 48 (Suppl. 1): 171.

Sánchez I, Salas R, Rodríguez R, Aular SM, Loaiza L C, Balzan C, Incani RN 1997. Esquistosomiasis mansoni en el Valle de Los Naranjos, Estado Carabobo, un foco de alta transmisión. II. Morbilidad. Act Cient Venez 48 (Suppl. 1): 171.

Tsang V, Hillyer G, Noh J, Vivas González B, Ahn L, Pilcher J, Hightower A, Deseda C, Feliciano de Melecio C 1997. Geographic clustering and seroprevalence of schistosomiasis in Puerto Rico (1995). Am J Trop Med Hyg 56: 107-112.

WHO 1985. The control of schistosomiasis. WHO Technical Report Series 728: 90-104. 